PRZEGLĄD RUSYCYSTYCZNY 2021, nr 3 (175)

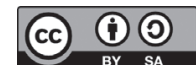

DOI 10.31261/pr.9050

\author{
ANNA ŚWIETLIK \\ Uniwersytet Wrocławski \\ (iD) 0RCID: http://orcid.org/0000-0001-6499-1016
}

\title{
JEWGIENIJ CHARITONOW — HOMO SACER LITERATURY ROSYJSKIEJ
}

\author{
YEVGENY KHARITONOV — HOMO SACER OF RUSSIAN LITERATURE
}

The article is devotef to the work of Yevgeny Kharitonov: the circumstances of the publication of copyright collections, as well as the distinguishing features of the works are presented. Also has been taken an attempt to determine the place of a homosexual literary character located in the soviet social space. The study was carried out using the concept of modern philosophers Giorgio Agamben and Julia Kristeva, as well as scientific works in the field of social queer theory.

Keywords: Russian gay literature, queer studies, USSR, Yevgeny Kharitonov, homo sacet

Miłość homoseksualna jest motywem niezwykle rzadkim w literaturze rosyjskiej. Historyczna sinusoida liberalizacji i zaostrzeń obyczajowych odcisnęła wyraźne piętno także w przestrzeni literackiej, czego potwierdzeniem jest znikoma liczba utworów podnoszących problematykę miłości jednopłciowej.

Pośród nielicznych rosyjskich reprezentantów tego niszowego nurtu szczególne miejsce zajmuje Jewgienij Charitonow - postać mało znana i zagadkowa, tak na gruncie polskim ${ }^{1}$ jak i rosyjskim. Celem niniejszej pracy jest usytuowanie twórczości autora w rosyjskiej przestrzeni historycznoliterackiej oraz uwypuklenie dystynktywnych cech jego utworów. Dla dopełnienia kontekstu przedstawione zostaną okoliczności długo wyczekiwanej publikacji tekstów pisarza. Odniesienie do społecznej teorii queer, a także koncepcji z zakresu filozofii pozwoli natomiast zdefiniować miejsce autora/bohatera $\mathrm{w}$ heteronormatywnej przestrzeni społeczno-kulturowej.

Lata 90. są okresem znamiennym, a zarazem unikatowym w rosyjskiej historii - transformacja masowej świadomości, która odcisnęła

${ }^{1} \mathrm{Na}$ język polski przetlumaczone zostało jedynie opowiadanie Духовка; zob. J. Charitonow, Duchówka, przeł. A. Pomorski, „Literatura na Świecie” 2018, nr 9-10. 
piętno na biografii każdego obywatela byłego ZSRR, doprowadziła do całkowitego przewartościowania dotychczasowej rzeczywistości $\mathrm{w}$ wymiarze instytucjonalnym, ekonomicznym, a przede wszystkim kulturowym. Należy podkreślić, że okres tzw. лихих девяностьхх był w Rosji czasem absolutnej liberalizacji każdej dziedziny kultury, szczególnie kultury masowej. Rosyjscy krytycy literaccy mówili wtedy o całkowitej erotyzacji literatury3. W przewrocie obyczajowo-kulturowym przełomowym dla przedmiotu moich badań okazał się rok 1993 - wtedy to dokonano depenalizacji homoseksualizmu w Federacji Rosyjskiej - zniesiony został niesławny 121. artykuł kodeksu karnego, na mocy którego pozbawionych wolności zostało około 60000 osób ${ }^{4}$. Należy podkreślić, że przerwanie ciszy na temat homoseksualizmu nastąpiło w ZSRR już w drugiej połowie lat 80. wraz z pieriestrojką, jednak o rzeczywistym wyzwoleniu i dekryminalizacji gejów można mówić dopiero w latach 90.

Po zniesieniu cenzury na młodym rosyjskim rynku wydawniczym pojawiła się literatura piękna zawierająca wątki homoerotyczne. Zaczęto wydawać także fachowe opracowania z zakresu medycyny, seksuologii i psychologii traktujące o homoseksualizmie po raz pierwszy inaczej niż o dewiacji czy zaburzeniu psychicznym ${ }^{5}$. Witalij Czernecki opisywał to wydarzenie jako „[...] bezprecedensowy renesans reprezentacji tekstowej, a także autoprezentacji najbardziej napiętnowanych i uciskanych grup mniejszościowych we współczesnej Rosji: gejów i lesbijek"6. Równie entuzjastycznie o zaistniałym przewrocie literacko-obyczajowym pisał Brian Bear:

${ }^{2}$ Lata 90. XX wieku są w Rosji do dziś określane w ten sposób z uwagi na katastrofalną sytuację gospodarczą kraju, powszechną przestępczość, prostytucje, korupcję i marazm panujący w społeczeństwie.

3 Zob. О. Дарк, Три лика русской эротики, „Стрелец” 1991, nr 3.

4 Badacze nie dysponują statystykami, na podstawie których można by wskazać dokładną liczbę osób skazanych za kontakty homoseksualne w ZSRR. Przybliżoną wartość podaje historyk i slawista Dan Healey; zob. Д. Хили, Гомосексуальное влечение в революционной России. Регулирование сексуально-гендерного диссидентства, przeł. Т. Логачева, В. Новиков, Ладомир, Москва 20о8, s. 311.

5 Szczególną uwagę należy zwrócić na prace socjologa, psychologa, pioniera radzieckiej i rosyjskiej seksuologii Igora Kona. Większość artykułów z lat 90. ukazała się jako rozdziały w książkach. zob. И. Кон, Лунный свет на заре. Лики и маски однополой любви, Олимп, Москва 1998; И. Кон, Любовъ небесного цвета, Продолжение Жизни, Москва 2001; И. Кон, Клубника на березке. Сексуальная культура в России, Время, Москва 2010.

6 V. Chernetski, Mapping postcommunism cultures, Russia and Ukraine in the Context of Globalization, McGill-Queen's University Press, Montreal 2007, s. 146, [tłum. moje - A.Ś]. 


\section{JEWGIENIJ CHARITONOW...}

Po wielu latach surowych represji wobec homoseksualistów i publicznej ciszy w sprawie homoseksualizmu w Rosji, otwarcie się narodu na kulturową globalizację zapoczątkowało szybką i dalekosiężną zmianę w podejściu społeczeństwa do homoseksualizmu, który zaczął tracić status tematu tabu [...] i powoli, ale pewnie przyciągał uwagę mediów i szerokiej publiczności.

Rzeczywistość wyglądała jednak nieco inaczej. Depenalizacja i detabuizacja homoseksualizmu w rosyjskiej przestrzeni społeczno-kulturowej nie wystarczyła, by przełamać głęboko zakorzenioną i latami pielęgnowaną niechęć czy wręcz odrazę do osób o odmiennych preferencjach seksualnych. Należy pamiętać, że decyzja rosyjskich władz o dekryminalizacji homoseksualizmu była czysto polityczna, o czym pisał Igor Kon:

В 1993 году была осуществлена декриминализация гомосексуальности. Сделано это было не потому, что власть стала просвещенной или испытывала сильное давление снизу (геевские организации реального влияния не имели, а всем остальным это было безразлично), а исключительно по политическим соображениям, чтобы войти в Совет Европы. Мотивы этого решения обществу не объяснили, просто отменили уголовную статью8 .

Zmianom w zapisach prawnych nie towarzyszyły kampanie uświadamiające lub wzmagające tolerancyjność wśród obywateli. Nie podjęto szczególnych wysiłków, by realnie polepszyć sytuację osób homoseksualnych w Rosji.

Niechęć społeczeństwa do „odmieńców” wynikała nie tylko ze wspieranej przez władze powszechnej stygmatyzacji zachowań nieheteronormatywnych, lecz przede wszystkim z nieświadomości i braku edukacji seksualnej obywateli byłego Związku Radzieckiego. W tym miejscu warto przytoczyć dobrze znaną wszystkim frazę „W ZSRR seksu nie ma” - ta niefortunna wypowiedź wyrwana

7 B. Baer, Other Russians Homosexuality and the Crisis of Post-Soviet Identity, Palgrave Macmillan, New York 2009, s. 2 [tłum. moje - A.Ś].

8 И. Кон, Гомофобия как лакмусовая бумажка российской демократии, „Вестник общественного мнения” 2007, $\mathrm{nr}$ 4, s. 59, https://cyberleninka.ru/article/n/gomofobiya-kak-lakmusovaya-bumazhka-rossiyskoy-demokratii/viewer (10.05.2020).

9 Te skrzydlate słowa padły z ust uczestniczki telemostu Leningrad - Boston w 1986 roku. Jeden z programów tego typu poświęcony był sytuacji kobiet w USA i Związku Radzieckim. Ze strony amerykańskiej zadane zostało pytanie: „U nas w reklamach, w telewizji wszystko kręci się wokół seksu. U was też są takie reklamy?” Po stronie radzieckiej jedna z pań odpowiedziała: „Seksu u nas nie ma i jesteśmy jemu kategorycznie przeciwni”. Dopiero po chwili inna uczestniczka 
z kontekstu stała się niezwykle celną diagnozą anty-seksualności sowieckiej kultury, która po części sformułowała dzisiejszą nietolerancyjność i konserwatywną obyczajowość Rosjan. Czy można więc mówić o dokonaniu się rewolucji seksualno-obyczajowej w przeciągu niespełna kilku lat w kraju, w którym na przestrzeni dziesięcioleci potępiano wszelkie próby odejścia od tzw. normy - patriarchalnej i heteroseksualnej hegemonii i jedynie właściwej normatywności? Postkomunistyczna rewolucja seksualna miała w Rosji miejsce, należy jednak pamiętać, że początek lat 90. to zaledwie jej inicjalne stadium. Nic zatem dziwnego, że nowa literatura tamtego okresu, manifestująca wszystko to, co dotychczas klasyfikowano jako nienaturalne seksualne aberracje, polaryzowała czytelników i krytyków. Normatywność seksualna, szczególnie w ZSRR, stanowiła sferę sacrum - nienaruszalny obszar społecznego ładu, wyjście poza który odczytywany był jako zamach na świat heteroseksualnej normy, zamach na moralny porządek kultywowany od dziesięcioleci, w końcu zamach na panujący ustrój. Dlatego znacznie bardziej kontrowersyjna i trudna w percepcji dla Rosjan okazała się nie zachodnia, lecz rodzima literatura homoseksualna osadzona w realiach epoki socjalizmu.

Jewgienij Władimirowicz Charitonow (1941-1981) przyszedł na świat w Nowosybirsku, pracował i tworzył w Moskwie, tam też zmarł. Był absolwentem moskiewskiego Wszechrosyjskiego Państwowego Instytutu Kinematografii, obronił rozprawę doktorską z zakresu pantomimy, którą zajmował się profesjonalnie w Moskiewskim Teatrze Mimiki i Gestu; wykładał w swojej macierzystej uczelni, a także w Moskiewskim Uniwersytecie Państwowym, pracował jako reżyser teatralny w kilku moskiewskich teatrach. To imponujące portfolio stanowi jedynie oficjalną część działalności artystycznej Charitonowa - ostatnie lata swojego życia poświęcił literaturze. Miłość homoseksualna, która była wiodącym motywem jego twórczości podyktowała przynależność autora do literackiego undergroundu. Zmarł nagle na zawał serca latem 1981 roku. Za życia Charitonow nie opublikował żadnego utworu, pojedyncze teksty ukazywały się od 1987 roku w czasopismach literackich ${ }^{10}$. Dopiero w 1993 roku, dzięki niemałym wysiłkom przyjaciół autora oraz działaczy rosyjskiego ruchu LGBT ukazało się na rynku dwutomowe wydanie zebranych dzieł Слёзы на

dodała: „Seks u nas jest, tylko reklam u nas nie ma!” Na sprostowanie było jednak za późno, a do powszechnego użytku weszła tylko część wypowiedzi.

${ }^{10}$ Pojedyncze utwory publikowano m.in. w czasopismach „Исскуство кино” (w części poświęconej literaturze), „Стрелец”, „Вестник новой литературы”. 
цветах ${ }^{11}$. Kilkanaście lat po śmierci zapomniany autor został okrzyknięty najważniejszym przedstawicielem rosyjskiej literatury homoerotycznej od czasów Michaiła Kuzmina ${ }^{12}$.

W 2005 roku w Rosji zostało opublikowane drugie wydanie zebranej twórczości Charitonowa, opatrzone nowymi komentarzami, tym razem pod tytułem Под домашним арестом ${ }^{13}$. Tytuł ten jest bardzo wymowny i znakomicie odzwierciedla problematykę utworów. Aby dobrze ją zrozumieć, należy wiedzieć, że Charitonow był homoseksualistą, czego szczególnie nie ukrywał - o jego preferencjach wiedziano w kręgach moskiewskiej bohemy. Niektórzy badacze twierdzą, że to właśnie orientacja seksualna autora była jego „surowcem artystycznym"14, czemu trudno zaprzeczyć. Interferencja zachodząca pomiędzy pozycją autora i bohatera jest niepodważalnym walorem autentyczności, co zauważał Lew Klejn:

Харитонов не играл гомосексуала, он им был, это общеизвестно. Авторская речь у него строго отделена от стилизованной речи персонажей. Если он и строил образы для эпатажных и критических целей, то он строил их из собственных переживаний, с неимоверной откровенностью и самокритичностью, выворачивал свою душу ${ }^{15}$.

Nie można z całą pewnością stwierdzić, że mamy tu do czynienia z prozą autobiograficzną sensu stricto, ponieważ istnieje bardzo niewiele materiałów ${ }^{16}$ jednoznacznie potwierdzających, że bezimienny bohater tych utworów stanowi alter ego autora. Można zatem przy-

${ }^{11}$ Zob. Е. Харитонов, Слезы на цветах: Сочинения. В 2-х кн., Глагол, Москва 1993.

${ }^{12}$ Mowa tu o Michaile Kuzminie (ros. Михаил Кузмин 1872-1936), pisarzu, poecie i kompozytorze okresu tzw. rosyjskiego srebrnego wieku, twórcy manifestów literackich klaryzmu. W 1906 roku na łamach czasopisma „Wiesy” miała miejsce premiera jego najbardziej znanej powieści Skrzydła (ros. Крылья), uważanej do dziś za sztandarowe dzieło rosyjskiej prozy homoerotycznej. Kuzmin był prekursorem tej tematyki na gruncie rosyjskim. Więcej o autorze zob. m.in.: E. Komisaruk, Proza Michaiła Kuzmina, Wydawnictwo Uniwersytetu Wrocławskiego, Wrocław 2002.

${ }^{13}$ Charitonow takim właśnie tytułem opatrzył jedyny maszynopis z zebranymi utworami.

14 А. Гольдштейн, О Евгении Харитонове, „Новое литературное обозрение” 1993, nr 3, s. 262.

15 Л. Клейн, Другая любовъ. Природа человека и гомосексуальность, ФолиоПресс, Санкт-Петербург 200о, s. 286.

${ }^{16}$ Główne źródło stanowią opracowania autorstwa przywoływanego Lwa Klejna, który wskazuje na powiązania bohaterów literackich z rzeczywistymi postaciami. 
jąć, że utwory te stanowią konglomerat rzeczywistych doświadczeń Charitonowa i fikcji literackiej, zaś narratorem jest sam autor. Nie można natomiast dokładnie określić proporcji prawdy i fantazji autora w tej mieszance.

Twórczość Charitonowa trudno sklasyfikować genologicznie z uwagi na heterogeniczność i amorficzność poetyki jego tekstów. Andrzej Drawicz uznaje dorobek literacki Charitonowa, jak i podobnych jemu autorów, za „prozę inną”, literaturę buntu, której zasadniczą cechą jest indywidualizm, polegający na wyzwoleniu się od uprzedniego respektowania nakazów ideologicznych ${ }^{17}$. Na podstawie niektórych cech dystynktywnych utworów można zaryzykować odniesienie Charitonowa do twórców postmodernistycznych. Jego teksty noszą również cechy psychologizmu, a swą strukturą nawiązują do koncepcji strumienia świadomości. Stylistyczny melanż właściwy prezentowanej twórczości podsumował Klejn, wskazując również na pozostałe zabiegi poetyckie:

Поток сознания, что-то от Джойса, что-то от обэриутов, что-то сугубо свое, новое, экстравагантное - то, что сейчас называется концептуализмом. Много психологических изысков, много стилизации под простецкого совка. Очень много субъективно-биографических сюжетов с самокопанием, самоиронией, саморазоблачениями. Разные фокусы с подачей текста - изгибание строчек, вертикальные строчки, одно слово на странице и т.п. ${ }^{18}$.

Celowo niestaranny zapis, przekreślone słowa, deformacje składniowe i stroficzne to „znak firmowy” Charitonowa. Jak twierdził Kirill Rogow, konceptualne eksperymenty ze strukturą tekstu nadają tym utworom charakteru sporządzanych odręcznie notatek ${ }^{19}$. Celne wydaje się określnie Dmitrija Prigowa, który pisał o Charitonowie jako o autorze konfesyjnym ${ }^{20}$ - całość, tak poetyka, jak i konstrukcja tekstów, utrzymana jest bowiem w konwencji intymnej notatki, dziennika lub prywatnego listu. Poza specyficznym kształtem utwory cechuje niespotykane słownictwo - Charitonow był pierwszym pi-

${ }^{17}$ Historia literatury rosyjskiej XX wieku, red. A. Drawicz, PWN, Warszawa 2002, S. 594 .

18 Л. Клейн, Другая сторона светила. Необычная любовъ выдающихся людей, Фолио-Пресс, Санкт-Петербург 2002, s. 537-538.

${ }^{19}$ К. Рогов, Экзистенциальный герой и „невозможное слово” Евгения Харитонова, w: Е. Харитонов, Под домашним арестом, red. С. Надеев, А. Шаталов, Глагол, Москва 2005, s. 7.

${ }^{20}$ Д. Пригов, Памяти Евгения Владимировича Харитонова, w: tamże, s. 91. 
sarzem, który wprowadził do literatury rosyjskiej slang mniejszości homoseksualnych ${ }^{21}$.

W przypadku twórców, którzy wprowadzają nowatorską problematykę do przestrzeni literackiej wskazuje się utwór pełniący funkcję manifestu, który określa charakter proponowanego przez twórcę novum. Charitonow zademonstrował autorską pozycje w eseju Листовка, którego pierwsze wersy brzmią: „Мы есть бесплодные гибельные цветы. И как цветы нас надо собирать в букеты и ставить в вазу для красоты” ${ }^{22}$. Metaforyczne ujęcie radzieckich homoseksualistów jako kwiatów, materii z natury pięknej i delikatnej zarazem jest niezwykle istotne dla zrozumienia koncepcji przyjętej przez autora. Charitonow dokonuje wyraźnego rozgraniczenia pomiędzy figurą heteroseksualnego radzieckiego mężczyzny, „русского мужика” (przynależącego do sfery moralnego sacrum), a przedstawicielem „голубого мира” (z uwagi na preferencje ze sfery sacrum wykluczonego). Ideałem rosyjskiej męskości jest zdefiniowana przez Raewyn Connell tzw. męskość hegemoniczna, opierająca się na przemocy i dominacji, sile fizycznej i agresji oraz wszelkich innych przejawach „prawdziwej męskości”, którymi są także mizoginia (tu rozumiana jako instrumentalne traktowanie kobiet) i naturalnie homofobia $^{23}$. To właśnie nienawiść wobec osób homoseksualnych jest w takim modelu zachowania gwarancją utrzymania pozycji „prawdziwego mężczyzny". Warto poświęcić w tym miejscu nieco uwagi przemyśleniom socjologa i filozofa Pierre'a Bourdieu. W pracy $\mathrm{Mę-}$ ska dominacja Bourdieu demaskuje mechanizm funkcjonowania takich zachowań. Męskość rozumiana jako sprawność reprodukcyjna, seksualna i społeczna definiuje wyzbycie się wrażliwości i czułości na rzecz agresji i siły. Męskość uzależniona jest w takim systemie od oceny wydawanej przez „prawdziwych mężczyzn”, tworzących męską wspólnotę. W takim schemacie nie można pozwolić sobie na utratę szacunku i aprobaty środowiska. Największy lęk wywołuje posądzenie o zniewieściałość czy homoseksualne pożądanie, co wyrażają właściwe kobietom „kategorie słabości”, jak np. mięczak, panienka, pedał $^{24}$. Taka afiliacja oznacza degradację i wykluczenie z sakralnej

${ }^{21}$ Gay Histories and Cultures, red. G. Haggerty, Garland Publishing, New York 2005 , s. 1167.

${ }^{22}$ Е. Харитонов, Листовка, w: tegoż, Под домашним..., s. 312.

${ }^{23}$ Encyklopedia gender, red. M. Rudaś-Grodzka, K. Nadana-Sokołowska i in., Czarna Owca, Warszawa 2014, s. 315.

${ }^{24}$ P. Bourdieu, Męska dominacja, przeł. L. Kopciewicz, Oficyna Naukowa, Warszawa 2004, s. 63-67. 
sfery normatywności. Tymczasem Charitonow prezentuje „kwiaty” jako ludzi obdarzonych wysmakowanym gustem, przewodników piękna, uwypuklając wiele cech nieprzystających do „prawdziwego mężczyzny” lub podających stereotypową "męskość” w wątpliwość. Status wyjątkowości, jaki autor nadaje mężczyznom o odmiennych preferencjach, oznacza wyłamanie się z systemu normatywnego, co jednocześnie definiuje „kwiaty” jako jednostki wobec tego systemu dysfunkcjonalne. Radzieccy homoseksualiści to kasta bezbronnych totalitarna machina może w każdej chwili rozprawić się z nimi, biorąc miłość do drugiego mężczyzny za ciężkie przewinienie. Sądzę, że to właśnie dlatego Charitonow przedstawia homoseksualistów niczym pomazańców Bożych, skazanych na doczesne cierpienia (życie na wewnętrznej emigracji), które zostaną zrekompensowane dopiero po śmierci:

И ясно тоже как Божий день, что именно все изнеженное, лукавое, все ангелы падения, все, что в бусах, бумажных цветах и слезах, все у Бога под сердцем; им первое место в раю и Божий поцелуй. Лучших из наших юных погибших созданий он посадит к себе ближе всех. А все благочестивое, нормальное, бородатое, все, что на земле ставится в пример, Господь хоть и заверяет в своей любви, но сердцем втайне любит не слишком ${ }^{25}$.

Charitonow nie tylko opiewa mężczyzn homoseksualnych jako męczenników, lecz wskazuje także na fatalny charakter odmienności: „Мы как избранные и предназначенные должны быть очерчены неприязненной чертой, чтобы наш пример не заражал"26. Złowroga aura to prowadzona przez dziesięciolecia antyhomoseksualna kampania, na skutek której większość społeczeństwa widziała w miłości dwóch mężczyzn jedynie seksualne wynaturzenie, co dawało względną gwarancję nierozprzestrzeniania się „choroby”. Mamy tu jednak do czynienia z pewną sprzecznością - państwo radzieckie nie przewidywało w szeregach swoich obywateli homoseksualistów, lecz także seryjnych morderców, maniaków seksualnych etc., dlatego regularnie zapewniano społeczeństwo, że tacy zwyrodnialcy w ZSRR zwyczajnie nie istnieją. Należy oczywiście podkreślić, że stawianie w tym samym szeregu osób o odmiennej orientacji i pospolitych przestępców, zboczeńców i socjopatów było drastycznym nadużyciem, jednak ówczesne władze celowo dążyły do takiego ujednolicenia, ukazując homoseksualistów jako szaleńców, dewiantów czy ludzi

${ }^{25}$ Е. Харитонов, Листовка, w: tegoż, Под домашним..., s. 312.

${ }^{26}$ Tamże, s. 314. 
zepsutych moralnie. Co więcej, radzieckie prawodawstwo posiadało stosowne narzędzia, tj. zapisy w kodeksie karnym, dzięki którym organy ścigania mogły owe niepożądane jednostki prześladować, traktując odmienną orientację jako przejaw antysystemowej dywersji. Jacek Kochanowski w pracy Spektakl i wiedza. Perspektywa społecznej teorii queer dokonał kategoryzacji represji stosowanych wobec homoseksualistów:

uruchamiane są przeciw nim mechanizmy kontroli zmierzające w dwóch kierunkach: albo w kierunku pozbycia się ich z przestrzeni społecznej (strategia antropofagiczna) albo ich renormalizacji (strategia antropoemiczna) ${ }^{27}$.

W Związku Radzieckim najczęściej wykorzystywano pierwszy wariant, skazując na więzienie i społeczną banicję homoseksualistów lub po prostu jednostki „niewygodne” - wspomnieć można chociażby proces reżysera Siergieja Paradżanowa ${ }^{28}$. Osoby homoseksualne podlegały z jednej strony ciągłej kontroli ze strony władz ${ }^{29}$, z drugiej zaś pozostawały „niewidzialne” - publiczna demonstracja odmiennych preferencji oznaczała w najlepszym razie obyczajowy skandal, w najgorszym zaś wyrok i w rezultacie śmierć cywilną.

Rosyjski artysta szkoły konceptualnej i jeden z pierwszych przedstawicieli rosyjskiego performansu - Dmitrij Prigow, we wspomnieniach o Jewgeniju Charitonowie pisał, że ten przeczuwał swoją śmierć, dlatego też ostatnie miesiące życia poświęcił zebraniu wszyst-

${ }^{27}$ J. Kochanowski, Spektakl i wiedza. Perspektywa społecznej teorii queer, Wydawnictwo Wschód-Zachód, Łódź 2009, s. 119.

${ }^{28}$ Pogłoski o homoseksualnych skłonnościach reżysera posłużyły do spacyfikowania jego awangardowej twórczości nagradzanej za granicami ZSRR, jednak nie aprobowanej przez radzieckie władze. Po premierze filmu Cienie zakazanych przodków Paradżanow ostatecznie stracił przychylność partyjnych decydentów i po serii rzekomych antyradzieckich wystąpień, w 1973 roku został skazany na 5 lat pozbawienia wolności. Za podstawę oskarżenia posłużył donos o gwałcie, jakiego miał się dopuścić na młodym członku KPZR. Proces miał czysto polityczny charakter, a rzeczywistymi przyczynami rozprawy z reżyserem był jego nonkonformizm, biseksualność której szczególnie nie ukrywał i alternatywny charakter twórczości. Paradżanow, dzięki wstawiennictwu zachodnich przedstawicieli kultury został uwolniony w 1977 roku, jednak przez kolejne 7 lat nie miał możliwości kręcenia filmów w Związku Radzieckim. Więcej o procesie i sylwetce reżysera zob. m.in. В. Кираснов, 69. Русские геи, лесбиянки, бисексуалы и транссексуалы. Биографии выдающихся россиян и современников, Колонна, Тверь 2005.

${ }^{29} \mathrm{O}$ korzeniach rosyjskiej homofobii, a także strategiach inwigilowania i walki władz z radzieckimi homoseksualistami pisał szczegółowo Dan Healy; zob. D. Healey, Russian homophobia from Stalin to Sochi, Bloomsbury, London 2018. 
kich tekstów i sporządzeniu kilku kopii maszynopisu ${ }^{30}$. Tytuł Под домашним арестом wydawał się proroczy. „Похоже, ни на что другое не рассчитывал. Недаром так и свою книгу назвал" ${ }^{1}-$ pisała Swietłana Bielajewa-Konegen po premierze pierwszego wydania książki. Przedwczesna śmierć Charitonowa spowodowała, że jego dorobek literacki stanowi hermetyczną całość, nienarażoną na ponowną ingerencję czy reinterpretację samego twórcy.

Dorobek obejmujący około dwanaście lat pracy to narracja prowadzona z tytułowego „aresztu domowego”, miejsca o podwójnym znaczeniu. Charitonow sytuuje akcje utworów nie w jednym konkretnym miejscu, lecz w niedookreślonej przestrzeni, na którą składa się wiele miejsc akcji. Jest ona z jednej strony przestrzenią obyczajowej swobody, azylem w którym autor/bohater nie musi ukrywać swojej odmienności, pewnym miniuniwersum, w którym bez obaw może przeżywać miłosne uniesienia, z drugiej zaś jest to wydzielona strefa, „cela”, do której wtrąciło go społeczeństwo respektujące jedynie heteronormę. Tabuizowanie odmiennych preferencji seksualnych przez totalitarny reżim doprowadziło do wytworzenia kategorii jednostki społecznie niepożądanej, wciąż jednak w społeczeństwie funkcjonującej, jedynie symulującej „normalność” na jego potrzeby. Charitonow manifestował tragizm takiego położenia „odmieńców”, a poprzez swoją subwersywną pozycję zarysował obraz radzieckiej przestrzeni społecznej z perspektywy queer jeszcze przed faktycznym pojawieniem się tego rodzaju dyskursu. Aby jednak doprecyzować status, jaki radziecki homoseksualista otrzymywał poprzez „niedopasowanie” do obowiązujących reguł obyczajowych, warto odnieść się do koncepcji proponowanych przez Julię Kristevę i Giorgio Agambena.

Kategorie wprowadzone do nauki przez dwójkę współczesnych filozofów są chętnie przytaczane przez teoretyków studiów queer i adaptowane na potrzeby takich badań, ponieważ pozwalają określić mechanizmy zachodzące pomiędzy społeczeństwem rządzącym się określoną normą, a jednostką do tej normy nieprzystającą. Pierwsza z nich, teoria abiektu autorstwa Julii Kristevej, zawarta została w pracy Potęga obrzydzenia - esej o wstręcie. W zjawisku abiektywizacji główną rolę odgrywa abiekt/wymiot definiowany przez autorkę jako „to, co zaburza tożsamość, system, ład. Co nie przestrzega granic,

${ }^{30}$ Д. Пригов, Памяти Евгения..., s. 89.

${ }^{31}$ С. Беляева-Конеген, По-прежнему под домашним арестом w: Е. Харитонов, Слёзы ..., s. 173. 
miejsc, zasad. Pewne pomiędzy, dwuznaczne, mieszane" ${ }^{2}$. Abiekt ma być opozycją do podmiotu, a więc jednostki pełnoprawnie funkcjonującej w społeczeństwie. W przywołanej wcześniej pracy Kochanowski pisał, że produkcja abiektów „zwymiotowanych” na zewnątrz systemu ma za zadanie chronić jego wnętrze, wytyczając jednocześnie zewnętrzne granice obszaru normatywnego ${ }^{33}$. Wymiot/abiekt posiada cechy wzbudzające wstręt, jest tym, co zaburza heteronormatywny system, jednak tkwi wewnątrz podmiotu, stanowi jego obcą, a zarazem integralną część. Wstręt, jaki społeczeństwo odczuwa względem homoseksualistów, prowadzi do ich wyobcowania, a także, o czym pisał Kochanowski, umocnienia pozycji „prawdziwego” mężczyzny, wytyczenia granicy normy. Abiekt, do którego można porównać bezimiennego narratora Charitonowa, tkwi we wrogiej mu przestrzeni i może być jej pełnoprawnym uczestnikiem tylko wówczas, gdy dopasuje się do społecznych heteronormatywnych reguł.

Druga koncepcja - homo sacer, prezentowana przez Giorgio Agambena skupia się na swego rodzaju stanie zawieszenia. Homo sacer to podmiot o niejasnym statusie prawnym, człowiek, który może być zabity przez kogokolwiek, lecz nie może zostać złożony jako ofiara, wykluczony ze społeczeństwa, zbędny i pozbawiony wszelkich praw, dalej jednak w tym społeczeństwie funkcjonujący ${ }^{34}$. Kochanowski dokonał transkrypcji koncepcji na potrzeby teorii queer, formułując ją następująco:

osoba homoseksualna zdaje się zyskiwać graniczny status opisywanego przez Giorgio Agambena homo sacer, istoty niezdolnej do wypowiedzenia siebie, pozbawionej znaczenia, funkcjonującej w zawieszeniu pomiędzy sacrum (tu: światem heteroseksualnej normy) a profanum (tu: światem dewiacji, od którego nakazuje się mu odciąć, jednocześnie skazując nań), pozostając w strefie nierozróżnialności, stając się banitą, paradoksalnie zamieszkującym oba światy, a nieprzynależącym do żadnego z nich ${ }^{35}$.

Na „wewnętrznym wygnaniu”, które opisuje Kochanowski, znajduję się bohater utworów Charitonowa. $\mathrm{Z}$ całą pewnością nie można określić go jako przedstawiciela sfery sacrum, a więc „normalnego”, heteroseksualnego obywatela radzieckiego, nie można też mówić

${ }^{32}$ J. Kristeva, Potęga obrzydzenia - esej o wstręcie, przeł. M. Falski, Wydawnictwo Uniwersytetu Jagiellońskiego, Kraków 2007, s. 10.

33 J. Kochanowski, Spektakl i wiedza..., s. 121.

${ }^{34}$ Zob. G. Agameben, Homo sacer. Suwerenna władza i nagie życie, przeł. M. Salwa, Prószyński i S-ka, Warszawa 2008.

35 J. Kochanowski, Spektakl i wiedza..., s. 29-30. 
o jego przynależności do sfery profanum, która w realiach radzieckich nie istniała jako taka. Zepchnięty na margines społeczny, funkcjonuje pomiędzy obydwoma światami jako homo sacer w świecie homo sovieticus.

Nadanie podmiotowi statusu homo sacer stanowi pewien paradoks: na mocy prawa skazuje się go na społeczną banicję, co znaczy, że instytucja, której podmiot jakoby nie jest podległy, ponieważ nie należy do świata zarządzanego przez tę instytucję (tu: świata heteronormatywnego sacrum), skazuje go na wygnanie, nadając mu tym samym tożsamość. Ujmując rzecz prościej, pozbawienie jednostki statusu „normalności” daje mu tym samym szansę na kreowanie własnej rzeczywistości, innej od narzuconej. O zaistniałym paradoksie pisał następująco Kochanowski:

zatem homo sacer zesłany jest na margines gestem władzy, jednak może tej władzy stawić opór przyjmując swój status marginesu i kuriozalności. Może przeżyć i tworzyć sensy o charakterze antynormatywnym. Jego trwanie będzie najcenniejszym świadectwem jakie może nam przynieść. Świadectwem o tym, że kuriozalność jest szansą, a nie przekleństwem ${ }^{36}$.

Bohater utworów Charitonowa to bez wątpienia homo sacer, sądzę jednak, że sam autor również posiadał omawiany graniczny status. Szansą stała się dla niego literatura - oto twórczość, będąca unikatowym świadectwem „kuriozalności” w czasach obligatoryjnej „normalności”.

Dorobek literacki Jewgenija Charitonowa jest bogaty w różnorodne zabiegi poetyckie i niejednoznaczny, co próbowałam zaprezentować w niniejszej pracy. Choć całość traktuje głównie o niespełnionej miłości, platonicznym uczuciu do drugiego młodzieńca/mężczyzny, to jest to także introspektywne studium osoby chorobliwie samotnej, dla której miłosne spełnienie pozostaje w sferze fantazmatycznej. Wykazałam także, jak sądzę, że pozycja autora/bohatera - wrażliwego intelektualisty, pozbawionego przez społeczeństwo prawa do otwartego manifestowania uczuć, znakomicie wpisuje się w koncepcje homo sacer oraz spełnia założenia właściwie dla abiektu.

${ }^{36}$ Tamże, s. 134. 


\section{REFERENCES}

Agameben, Giorgio. Homo sacer. Suwerenna władza i nagie życie. Transl. Salwa, Mateusz. Warszawa: Prószyński i S-ka, 2008.

Baer, Brian. Other Russians. Homosexuality and the Crisis of Post-Soviet Identity, New York: Palgrave Macmillan, 2009, (digital edition, ISBN: 9780230612242).

Belyayeva-Konegen, Svetlana. "Po-prezhnemu pod domashnim arestom." in: Kharitonov, Yevgeniy. Slëzy na tsvetakh. Nadeyev, Sergey, and Shatalov Aleksandr (Eds.). T. 2. Moskva: Glagol, 1993 [Беляева-Конеген, Светлана. "По-прежнему под домашним арестом.” Харитонов, Евгений. Слёзы на цветах, Надеев, Сергеев, Шаталов Александр (ред.). Т. 2, Moskva: Глагол, 1993].

Bourdieu, Pierre. Męska dominacja. Transl. Kopciewicz, Lucyna. Warszawa: Oficyna Naukowa, 2004.

Chernetski, Vitaly. Mapping postcommunism cultures. Russia and Ukraine in the Context of Globalization, Montreal: McGill-Queen's University Press, 2007 (digital edition, ISBN: 9780773531239).

Dark, Oleg. “Tri lika russkoy erotiki.” Strelets 1991, no. 3 [Дарк, Олег. “Три лика русской эротики." Стрелец 1991, nо. 3].

Encyklopedia gender. Pteć w kulturze. Rudaś-Grodzka, and Monika, NadanaSokołowska, Katarzyna at all. (Eds.). Warszawa: Czarna Owca, 2014.

Gay Histories and Cultures, Haggerty, George (Ed.). New York: Garland Publishing, 2005 (digital edition, ISBN: 0203796128).

Gol'dshteyn, Aleksandr. "O Yevgenii Kharitonove." Novoye literaturnoye obozreniye 1993, no. 3 [Гольдштейн, Александр. “О Евгении Харитонове.” Новое литературное обозрение 1993, no. 3].

Healey, Dan. Russian homophobia from Stalin to Sochi. London: Bloomsbury, 2018 (digital edition, ISBN: 9781350000803).

Historia literatury rosyjskiej XX wieku. Drawicz, Andrzej (Ed.). Warszawa: PWN, 2002.

Kharitonov, Yevgeniy. Pod domashnim arestom. Moskva: Glagol, 2005 [Харитонов, Евгений. Под домашним арестом. Москва: Глагол, 2005].

Kharitonov, Yevgeniy. Slezy na tsvetakh: Sochineniya. V 2-kh kn. Moskva: Glagol, 1993 [Харитонов, Евгений. Слезы на цветах: Сочинения. В 2-х кн. Москва: Глагол, 1993].

Khili, Dan. Gomoseksual'noye vlecheniye v revolyutsionnoy Rossii. Regulirovaniye seksual'no-gendernogo dissidentstva. Transl. Logacheva, Tamara, and Novikov, Vladimir. Moskva: Ladomir, 2008 [Хили, Дан. Гомосексуальное влечение в революционной России. Регулирование сексуально-гендерного диссидентства. Transl. Логачева, Тамара, and Новиков, Владимир. Москва: Ладомир, 2008].

Kirasnov, Vladimir. 69. Russkiye gei, lesbiyanki, biseksualy itransseksualy. Biografii vydayushchikhsya rossiyan i sovremennikov. Tver': Kolonna 2005 [Кираснов, Владимир. 69. Русские геи, лесбиянки, бисексуалы и транссексуалы. Биографии выдающихся россиян и современников. Тверь: Колонна, 2005].

Kleyn, Lev. Drugaya lyubov'. Priroda cheloveka i gomoseksual'nost'. Sankt-Peterburg: Folio-Press, 2000 [Клейн, Лев. Другая любовъ. Природа человека и гомосексуальность. Санкт-Петербург: Фолио-Пресс, 200о].

Kleyn, Lev. Drugaya storona svetila. Neobychnaya lyubov' vydayushchikhsya lyudey. Rossiyskoye sozvezdiye. Sankt-Peterburg: Folio-Press, 2002 [Клейн, 
Лев. Другая сторона светила. Необычная любовь выдающихся людей. Российское созвездие. Санкт-Петербург: Фолио-Пресс, 2002].

Kochanowski, Jacek. Spektakl i wiedza. Perspektywa społecznej teorii queer. Łódź: Wydawnictwo Wschód-Zachód, 2009.

Kon, Igor'. "Gomofobiya kak lakmusovaya bumazhka rossiyskoy demokratii." Vestnik obshchestvennogo mneniya 2007, no. 4 <https://cyberleninka.ru/article/n/ gomofobiya-kak-lakmusovaya-bumazhka-rossiyskoy-demokratii/viewer $>[\mathrm{Koн}$, Игорь. "Гомофобия как лакмусовая бумажка российской демократии." Вестник общественного мнения 2007, no. 4].

Kristeva, Julia. Potęga obrzydzenia - esej o wstręcie. Transl. Falski, Maciej. Kraków: Wydawnictwo Uniwersytetu Jagiellońskiego, 2007.

Prigov, Dmitriy. "Pamyati Yevgeniya Vladimirovicha Kharitonova." Kharitonov, Yevgeniy. Slëzy na tsvetakh. Nadeyev, Sergey, and Shatalov, Aleksandr (Eds.). T. 2, Moskva: Glagol, 1993 [Пригов, Дмитрий. "Памяти Евгения Владимировича Харитонова.” Харитонов, Евгений. Слёзы на цветах, Надеев, Сергей, and Шаталов, Александр (Eds.). Т. 2, Москва: Глагол, 1993].

Rogov, Kirill. “Ekzistentsial'nyy geroy i ,'nevozmozhnoye slovo' Yevgeniya Kharitonova." Kharitonov Yevgeniy. Pod domashnim arestom. Shatalov, Aleksandr (Ed.). Moskva: Glagol, 2005 [Рогов, Кирилл. "Экзистенциальный герой и 'невозможное слово' Евгения Харитонова.” Харитонов, Евгений. Под домашним арестом. Шаталов, Александр (Ed.). Москва: Глагол, 2005]. 